\title{
FINANCIAL PERFORMANCE INDICATORS OF SMALL AND MEDIUM-SIZED ENTERPRISES IN THE REPUBLIC OF CROATIA
}

\author{
Slobodanka Stjepanović1, \\ Melita Cita ${ }^{2}$ \\ ${ }^{1}$ Faculty of Economics in Osijek, \\ Osijek, Croatia \\ 'VERN' University of Applied Science, \\ Zagreb, Croatia
}

\begin{abstract}
:
Small and medium-sized companies are the backbone of a country's economic growth. The number of small and medium-sized companies has significantly increased in the last ten years as opposed to a decreasing number of large companies on an annual basis. In light of their increasing influence on the economic growth, this paper focuses on defining financial performances of the select economic activities by comparing their financial ratios. The paper aims at defining the condition, structure and changes of the select activities as well as analyses their performances in the period from 2008 to 2014 in order to determine their impact on the overall state of the economy. The analysis of the select activities was conducted by determining financial ratios on the basis of data collected from secondary sources on a sample of 50 companies from ten major business activities. The conducted research has found that the economy depends on performance characteristics of several activities, which may have a negative impact on the overall economy in the Republic of Croatia.
\end{abstract}

Keywords:

small and medium-sized entreprises, financial ratios, financial performances.

\section{INTRODUCTION}

Small and medium-sized companies are the backbone of a country's economic growth. The number of small and medium-sized companies in the Republic of Croatia has significantly increased in the last ten years as opposed to a decreasing trend of large companies on an annual basis. As per data gathered by the Croatian Chamber of Economy ${ }^{1}$, the number of large economic entities in 2008 was 453 , and of small and medium-sized ones it was 89,203 compared to 348 of the former and 106,221 of the latter in 2015. In other words, small and medium-sized companies in the Republic of Croatia accounted for 99.67\% of the overall number of companies in 2015.

The paper will analyse the changes in the financial ratios of small and mediumsized companies in the period 2008-2014. The research question was phrased in the following way: Does the entire Croatian economy depend on the financial performance of small and medium-sized companies in select activities? The answer thereto will be attempted to be offered by analysing the current ratio, leverage, ROA and ROE trends in the period from 2008 to 2014. The research was conducted on the basis of available official data published on http://rgfi.fina.hr ${ }^{2}$ and http://www.poslovna.hr ${ }^{3}$ for 50 small and medium-sized Croatian companies in ten activities ${ }^{4}$ by analyzing five companies per activity.

Following the introduction, this paper will first make theoretical assumptions about small and medium-sized companies and the select financial ratios. It will be followed by defining the sample, the applied research methodology, as well as the analysis and interpretation of the research findings, which will be summarised in the conclusion.

1 Gospodarska kretanja 3/4/2017 (2017) - (Economic Trends), Croatian Chamber of Economy, 74, available on: https://www.hgk.hr/documents/gospodarskakretanja030459253b851794d.pdf

2 Annual Financial Statements Registry

3 Croatian Business Portal

4 Listed in Chapter 3 
THEORETICAL ASSUMPTIONS AND THE OVERVIEW OF RESEARCH TO-DATE

The classification of the companies in the Republic of Croatia has been defined under the Accountancy Act and the Act on Stimulating Small Business Growth. As per the Accountancy Act ${ }^{5}$, 'the companies are classified into micro, small, medium-sized and large depending on the indicators provided on the last day of the business year preceding the business year for which the financial statements are released. Indicators used for the classification of business entities include:

- total assets

- revenue

- average number of workers during the business year'.

As per the Act on Stimulating Small Business Growth ${ }^{6}$, 'small economy in terms of the said Act is made up of the entities:

1. which employ an average of less than 250 workers per year

2. which are autonomous in their business operations

3. whose overall annual turnover does not exceed HRK $60,000,000.00$, or whose sum of balance, provided they are corporate tax payers, or whose fixed asset, provided they are income tax payers, does not exceed the value of HRK $30,000,000.00 \ldots$..In terms of size, companies are classified into micro, small and medium-sized small businesses.'

Numerous authors have analysed the operation of small and medium-sized companies from various aspects. The analysis of these companies during the economic crisis in Croatia conducted by Juračak and Pranjić ${ }^{7}$ has found them to be more sensitive to general conditions of operations and markets then large companies.

During his address at the $19^{\text {th }}$ Croatian Money Market Scientific Conference in Opatija, Mr. Boris Vujčić, the Governor of the Croatian National Bank ${ }^{8}$ pointed to the increasing importance of small and medium-sized businesses for the Croatian economy 'in recent years, and in particular

5 Accountancy Act, Official Gazette 78/2015, 34/2015, 120/2016

6 Act on Stimulating Small Business Growth, Official Gazette 29/2002, 63/2007, 53/2012, 56/2013, 121/2016

7 Juračak, J., Pranjić, D. (2014). Mala i srednja poduzeća u uvjetima gospodarske krize u Hrvatskoj (Small and Medium-Sized Companies in Times of Economic Crisis in Croatia), Faculty of Agriculture Osijek, 49th Croatian \& 9th International Symposium on Agriculture, Dubrovnik, 146-150.

8 Vujčić, B. (2016), Gospodarski izgledi u 2016. godini - jačanje konkurentnosti i rast (Economic Forecast in 2016 - Strengthening of Competition and Growth). 19th Scientific Conference on the Croatian Financial Market (Hrvatsko novčano tržište), available on https://www.hnb.hr/documents/20182/497904/hn05052 016_Vujcic_govor_Opatija.pdf/10b34d0e-a4a1-4b66-aa2bd4f69dee547f? version $=1.4$

9 Dudić, Z., Cvijić, M. (2017). Development of small and medium - sized enterprises in the Republic of Serbia and the Republic of Croatia, Education for Entrepreneneurship, Vol.7 NR1,129 -140, available on: https://hrcak.srce.hr/183428 following the EUaccession, when the importance of medium-sized and small companies in the overall export results has risen. In addition, these companies, medium-sized in particular, had a more potent effect on the overall labour productivity trend in Croatia during the post-crisis years.'

Dudić and Cvijić presented an overview of the situation of small and medium-sized enterprises in the Republic of Croatia and the Republic of Serbia which has found that "The sectors in which SMEs create the highest added value and employ most people are the wholesale and retail trade, followed by manufacturing, construction, business services, and provision of accommodation and food. ...Businesses in Croatia are in a better position than businesses in RS, because they have easier access to various EU funds since Croatia is one of the Member States". ${ }^{9}$ Bistričić, Agatić and Trošić considered the business of SMEs in Croatia and neighboring countries that are also members of the European Union and have found that "The relative importance of small and medium-sized enterprises to the Slovenian economy is in range of the European Union average. ...The employment share in Italy is $81.3 \%$, while the share of the added value is $70.9 \%$ for the small and medium-sized enterprises sector. The largest share in Italy, in comparison to the two other states, is not surprising, considering the very good economic development of Italy". ${ }^{10}$

Nanić talks about small and medium-sized enterprises as bearers of economic development of the European Union and emphasizes that "Small and medium-sized enterprises as the main generators of employment and economic development play a key role in the economy of the European Union. According to official statistics of the EU, about $99.8 \%$ of them are just small and medium-sized enterprises, and thus make a priority of economic development". ${ }^{11}$ As regards SMEs in BiH Džafić points out that "In Bosnia and Herzegovina $(\mathrm{BiH})$, there is entrepreneurial initiative but without significant government support in the realization of business ideas of potential entrepreneurs, though their personal success brings benefits to the whole society". ${ }^{12}$

As per data of the Croatian Chamber of Economy ${ }^{13}$ for the period 2008 - 2015, a share of small and medium-sized

10 Bistričić, A., Agatić, A., Trošić, N. (2011). Značaj poslovanja malih i srednjih poduzeća u gospodarstvu Republike Hrvatske i gospodarstva zemalja Europske Unije. (The Importance of Small and Medium- sized Enterprises in the Croatian Economy and the European Union States Economies). Rijeka: Časopis Pomorstvo, 25/1, 145 -158 (Scientific Journal of Maritime Research, 145-158)

11 Nanić, A. (2011). Mala i srednja poduzeća kao nosilac razvoja privrede europske unije (Small and medium enterprises as head of business of the European Union), available on: https://hrcak.srce. $\mathrm{hr} /$ file/159709

12 Džafić, Z. (2014 ). Pravci rasta i razvoja bosansko hercegovačke privrede - mala i srednja vs. velika poduzeća (Patterns of Growth and Development of the BIH Economy - Small and Medium Versus Large Companies), available on: https://www.researchgate. net/profile/Zijad_Dzafic/

13 Gospodarska kretanja 3/4/2017 (2017) - (Economic Trends), Croatian Chamber of Economy, available on: https://www.hgk.hr/documents/gospodarskakretanja030459253b851794d.pdf 
companies in the total number of businesses accounted for over $99 \%$ throughout observed years. A positive trend in favour of small and medium-sized companies is also seen in terms of the number of employees across company types i.e. large companies accounted for $33.74 \%$ of the total number of employees in 2008 compared to $66.26 \%$ employed by the small and medium-sized ones. The share of the employees in small and medium-sized companies in 2015 increased to $69.18 \%$, leaving large companies at $30.82 \%$. In terms of recorded income, $54 \%$ of the overall income was earned by small and medium-sized companies while large businesses accounted for about $46 \%$. All of the above points to a significant role of small and medium-sized businesses in the development of the Croatian economy.

In terms of financial indicators, numerous financial ratios have been developed, which can be grouped as follows:

1. liquidity ratios: measure a company's ability to meet its due short-term debt obligations

2. solvency/leverage ratios: measure the volume of the company's funds obtained by borrowing

3. activity ratios: measure the efficiency of the company's use of its resources (assets)

4. efficiency ratios: measure the income/cost ratio i.e. show the volume of income earned per unit of cost

5. profitability ratios: measure the return on invested capital (own and loan), considered to be the highest level of management effectiveness

6. investment ratios: measure the profitability of making investments in regular shares. ${ }^{14}$

There are several indicators within each of these groups. This paper will analysize the current ratio, leverage, ROA and ROE trends in the period from 2008 to 2014 of the select small and medium-sized companies.

The current ratio is an indicator of the proportion of current assets to current liabilities. As a rule, this ratio should not exceed two.

The leverage ratio is an indicator of the proportion of total liabilities to total assets. It shows how much asset was funded by gearing.

Return on Asset (ROA) is an indicator of how profitable a company is relative to its total available assets i.e. it indicates the ratio of profit strength to stockholders' investment.

Return on Equity (ROE) is the net profit/equity ratio which shows how much net profit per equity unit is earned. ROE 'is a significant measure of the company's profitability from the point of view of owners who invested their equity as well as a basic measure of profit planning.' ${ }^{15}$

14 Žager K., Mamić Sačer I., Sever Mališ S., Ježovita A. \& Žager L. (2017). Analiza financijskih izvještaja (The Financial Statements Analysis). Third amended and supplemented edition. Zagreb: Croatian Association of Accountants and Financial Experts, 44.

15 Belak V. (2014). Analiza poslovne uspješnosti : 130 ključnih pokazatelja performanse i mjerila za kontroling (The Analysis of Business Success: 130 key performance indicators and Controlling

\section{SAMPLING AND RESEARCH METHODOLOGIES}

This research focused on small and medium-sized companies in the Republic of Croatia which have an obligation to publish their annual financial statements. As all financial data was obtained from the Annual Financial Statements Registry maintained by the Financial Agency (FINA), the company selection criteria included the following: the business was obliged to publish financial statements, it was operational from 2008 to 2014, and it was classified as a small or medium-sized company under the Accountancy Act.

The next step of the empirical research was to collect data on small and medium-sized companies by business activity. The basic criterion for the classification of business activities in this paper was the National Classification of Activities 2007 - NKD $2007^{16}$, which came into effect on 1 January 2008. It is harmonized with the European standards i.e. its content and structure corresponds in full to the NACE Rev. 2. The analysis selected five businesses per activity.

The following activities were included: G. Wholesale and Retail Trade: repair of motor vehicles and motorcycles, $\mathbf{M}$. Professional, Scientific and Technical Activities, C. Manufacturing, F. Construction I. Accommodation and Food Service Activities, J. Information and Communication, L. Real Estate Activities N. Administrative and Support Service Activities H. Transportation and Storage S. Other Service Activities.

After the above stated criteria were met, the liquidity, leverage, ROA and ROE analysis was conducted for the period 2008-2014 for the select small and medium-sized companies.

\section{RESEARCH FINDINGS AND DISCUSSION}

The liquidity ratio during the observed period shows that the select companies dealt with the issue of liquidity, which exceeded the minimum recommended level of 2.0 as late as 2013 and 2014. If the liquidity ratio is observed by activities, it can be noted that $80 \%$ of businesses had liquidity issues assuming the minimum satisfactory liquidity ratio of 2.0. It can also be noted that the average ratio is much above 2.0 in real estate activities and the construction. It has been assumed that the reason for a high liquidity ratio are uncollected receivables or a stock holding period. Insolvency is pouring from one into another mutually linked activity. For example, insolvency in Accommodation and Food Service Activity is reflected on insolvency in Wholesale and Retail Trade.

Table 1 shows the calculation of the liquidity ratio by activities during the observed period.

16 National Classification of Activities 2007, Official Gazette 58/2007 
Table 1 . The overview of the liquidity ratio calculated by activities in the period 2008-2014

\begin{tabular}{lllllllllc}
\hline Activity & 2008 & 2009 & 2010 & 2011 & 2012 & 2013 & 2014 & Average & Ranking \\
\hline Activity G & 1.09 & 1.22 & 0.86 & 0.79 & 1.01 & 0.08 & 1.05 & $\mathbf{0 . 8 7}$ & $\mathbf{1 1}$ \\
\hline Activity M & 1.35 & 1.46 & 1.40 & 1.55 & 2.29 & 2.24 & 2.07 & $\mathbf{1 . 7 6}$ & $\mathbf{6}$ \\
\hline Activity C & 1.30 & 1.90 & 1.52 & 1.99 & 1.75 & 1.82 & 2.21 & $\mathbf{1 . 7 8}$ & $\mathbf{5}$ \\
\hline Activity F & 1.72 & 1.83 & 2.08 & 1.83 & 1.27 & 2.60 & 19.68 & $\mathbf{4 . 4 3}$ & $\mathbf{2}$ \\
\hline Activity I & 2.66 & 1.12 & 0.78 & 0.73 & 0.50 & 0.50 & 0.70 & $\mathbf{1 . 0 1}$ & $\mathbf{7}$ \\
\hline Activity J & 1.59 & 1.59 & 1.60 & 1.95 & 1.55 & 2.03 & 2.13 & $\mathbf{1 . 7 8}$ & $\mathbf{4}$ \\
\hline Activity L & 1.77 & 3.09 & 5.21 & 6.83 & 7.6 & 10.04 & 9.60 & $\mathbf{6 . 3 0}$ & $\mathbf{1}$ \\
\hline Activity N & 0.95 & 0.90 & 0.86 & 0.91 & 0.86 & 0.93 & 1.42 & $\mathbf{0 . 9 8}$ & $\mathbf{8}$ \\
\hline Activity H & 0.63 & 0.76 & 1.07 & 1.24 & 1.02 & 0.82 & 0.93 & $\mathbf{0 . 9 2}$ & $\mathbf{9}$ \\
\hline Activity S & 2.19 & 1.65 & 1.51 & 2.07 & 1.71 & 2.21 & 1.96 & $\mathbf{1 . 9 0}$ & $\mathbf{3}$ \\
\hline Average & $\mathbf{1 . 4 1}$ & $\mathbf{1 . 5 3}$ & $\mathbf{1 . 6 7}$ & $\mathbf{1 . 9 5}$ & $\mathbf{1 . 9 2}$ & $\mathbf{2 . 1 9}$ & $\mathbf{2 . 1 8}$ &
\end{tabular}

Source: Authors' calculations on the basis of RGFI data (Annual Financial Statements Registry)

Looking at the leverage ratio, a high rate of indebtedness can be observed by periods and by activities, where the said rate exceeds desirable $50 \%$. The leverage ratio is the lowest in the Real Estate Activities and the Construction, which is satisfactory although it may point to the overpriced assets in the company balance sheet. In terms of the leverage ratio by years, the effect of the economic crisis on the business operations of small and medium-sized companies is observed in view of the highest average leverage ratio of $96.23 \%$ in 2009 .

Table 2. The overview of the leverage ratio by activities in the period 2008-2014

\begin{tabular}{lccccccccc}
\hline Activity & 2008 & 2009 & 2010 & 2011 & 2012 & 2013 & 2014 & Average & Ranking \\
\hline Activity G & 70.03 & 76.85 & 76.47 & 78.03 & 75.95 & 72.25 & 64.46 & $\mathbf{7 3 . 4 3}$ & $\mathbf{8}$ \\
\hline Activity M & 66.03 & 60.56 & 61.00 & 74.00 & 61.60 & 59.80 & 50.40 & $\mathbf{6 1 . 9 1}$ & $\mathbf{6}$ \\
\hline Activity C & 72.22 & 152.09 & 151.63 & 97.07 & 103.66 & 91.38 & 58.84 & $\mathbf{1 0 3 . 8 4}$ & $\mathbf{1 0}$ \\
\hline Activity F & 46.83 & 43.46 & 46.97 & 55.28 & 55.24 & 38.07 & 27.48 & $\mathbf{4 4 . 7 6}$ & $\mathbf{1}$ \\
\hline Activity I & 60.07 & 60.26 & 73.16 & 58.95 & 63.11 & 61.09 & 58.06 & $\mathbf{6 2 . 1 0}$ & $\mathbf{7}$ \\
\hline Activity J & 59.53 & 55.73 & 55.04 & 58.42 & 64.53 & 57.89 & 54.80 & $\mathbf{5 7 . 9 9}$ & $\mathbf{4}$ \\
\hline Activity L & 56.54 & 40.73 & 33.61 & 41.21 & 50.95 & 60.13 & 41.82 & $\mathbf{4 6 . 4 4}$ & $\mathbf{2}$ \\
\hline Activity N & 61.40 & 63.51 & 66.51 & 57.64 & 61.68 & 58.30 & 52.34 & $\mathbf{6 0 . 2 0}$ & $\mathbf{5}$ \\
\hline Activity H & 77.93 & 74.10 & 73.07 & 71.66 & 76.59 & 79.04 & 73.91 & $\mathbf{7 5 . 1 9}$ & $\mathbf{9}$ \\
\hline Activity S & 62.87 & 57.97 & 55.93 & 48.82 & 57.49 & 47.11 & 46.72 & $\mathbf{5 3 . 8 4}$ & $\mathbf{3}$ \\
\hline Average & $\mathbf{6 4 . 3 5}$ & $\mathbf{9 6 . 2 3}$ & $\mathbf{8 0 . 5 0}$ & $\mathbf{7 5 . 6 1}$ & $\mathbf{7 2 . 0 0}$ & $\mathbf{7 1 . 0 0}$ & $\mathbf{5 9 . 0 3}$ & \\
\hline
\end{tabular}

Source: Authors' calculations on the basis of RGFI data (Annual Financial Statements Registry)

Profitability ratios include ROE and ROA. The analysis of the observed companies by activities has shown large differences. For example, Activity S - Other Service Activities has the equity rate of return of $18.5 \%$ compared to $1 \%$ in Trade. The Wholesale and Retail Trade has low equity and asset rates of return, whose declining trend since 2008 can be explained by competition.
The equity rate of return in Other Service Activities is $18.5 \%$ compared to $30.7 \%$ of ROA indicating a succeessful usage of financial leverage in business operations. Leverage was also successfully used in Activity M. 
Table 3. The overview of ROA calculations by activities in the period 2008-2014

\begin{tabular}{lccccccccc}
\hline Activity & 2008 & 2009 & 2010 & 2011 & 2012 & 2013 & 2014 & Average & Ranking \\
\hline Activity G & 9.7 & -5.1 & -0.9 & -0.0 & -0.7 & 0.2 & 4.4 & $\mathbf{1 . 1}$ & $\mathbf{1 0}$ \\
\hline Activity M & 7.3 & 9.2 & 23.2 & 23.3 & 7.1 & 4.2 & 15.3 & $\mathbf{1 2 . 8}$ & $\mathbf{3}$ \\
\hline Activity C & 8.9 & 1.9 & -12.7 & 48.7 & 0.6 & 5.1 & 11.3 & $\mathbf{9 . 1}$ & $\mathbf{4}$ \\
\hline Activity F & -2.3 & 11.3 & 5.8 & 4.6 & 5.1 & 21.7 & 7.6 & $\mathbf{7 . 6}$ & $\mathbf{7}$ \\
\hline Activity I & 6.3 & 3.1 & 1.0 & 2.1 & 1.4 & 4.1 & -5.3 & $\mathbf{1 . 8}$ & $\mathbf{9}$ \\
\hline Activity J & 10.6 & 17.9 & -0.8 & 2.9 & 7.6 & 7.2 & 10.0 & $\mathbf{7 . 9}$ & $\mathbf{6}$ \\
\hline Activity L & 25.8 & 27.5 & 24.3 & 27.9 & 12.4 & -2.1 & -16.5 & $\mathbf{1 4 . 1}$ & $\mathbf{2}$ \\
\hline Activity N & 2.9 & 4.2 & 7.2 & 9.0 & 8.8 & 9.7 & 17.3 & $\mathbf{8 . 4}$ & $\mathbf{5}$ \\
\hline Activity H & 8.7 & 8.9 & 5.2 & 6.8 & 4.9 & 5.7 & -12.4 & $\mathbf{3 . 9}$ & $\mathbf{8}$ \\
\hline Activity S & 14.9 & 24.5 & 16.9 & 27.1 & 18.8 & 16.2 & 11.3 & $\mathbf{1 8 . 5}$ & $\mathbf{1}$ \\
\hline Average & $\mathbf{9 . 3}$ & $\mathbf{1 0 . 3}$ & $\mathbf{6 . 9}$ & $\mathbf{1 5 . 2}$ & $\mathbf{6 . 6}$ & $\mathbf{6 . 6}$ & $\mathbf{4 . 3}$ &
\end{tabular}

Source: Authors' calculations on the basis of RGFI data (Annual Financial Statements Registry)

Table 4. The overview of ROE calculations by activities in the period 2008-2014

\begin{tabular}{lccccccccc}
\hline Activity & 2008 & 2009 & 2010 & 2011 & 2012 & 2013 & 2014 & Average & Ranking \\
\hline Activity G & 5.08 & -93.9 & -75.4 & -10.5 & -8.50 & 1.70 & 2.10 & $\mathbf{- 2 5 . 6 2}$ & $\mathbf{1 0}$ \\
\hline Activity M & 36.57 & 33.83 & 33.05 & 33.18 & 31.67 & 31.98 & 40.37 & $\mathbf{3 4 . 3 8}$ & $\mathbf{1}$ \\
\hline Activity C & 0.56 & 0.44 & 0.38 & 0.39 & 0.37 & 1.75 & 6.65 & $\mathbf{1 . 5 1}$ & $\mathbf{7}$ \\
\hline Activity F & 1.43 & 1.57 & 1.84 & 1.63 & 1.03 & 1.37 & 1.63 & $\mathbf{1 . 5 0}$ & $\mathbf{8}$ \\
\hline Activity I & -13.4 & 18.27 & 8.29 & 7.88 & 9.88 & 18.82 & -26.7 & $\mathbf{3 . 3 0}$ & $\mathbf{6}$ \\
\hline Activity J & 25.05 & 23.09 & -4.94 & -1.83 & -50.5 & 12.22 & 24.84 & $\mathbf{4 . 0 0}$ & $\mathbf{5}$ \\
\hline Activity L & 45.68 & 26.64 & 25.71 & 23.14 & 29.47 & -40.2 & -128. & $\mathbf{- 2 . 5 2}$ & $\mathbf{9}$ \\
\hline Activity N & 2.48 & 33.94 & 43.47 & 43.33 & 38.85 & 27.39 & 20.66 & $\mathbf{3 0 . 0 2}$ & $\mathbf{3}$ \\
\hline Activity H & 25.81 & 30.52 & 17.68 & 27.52 & 24.86 & 1.72 & 12.42 & $\mathbf{2 0 . 0 7}$ & $\mathbf{4}$ \\
\hline Activity S & 25.26 & 40.03 & 41.89 & 37.07 & 28.19 & 24.90 & 17.60 & $\mathbf{3 0 . 7 0}$ & $\mathbf{2}$ \\
\hline Average & $\mathbf{1 5 . 4 5}$ & $\mathbf{1 1 . 4 4}$ & $\mathbf{7 . 7 3}$ & $\mathbf{3 . 3 5}$ & $\mathbf{1 0 . 5 5}$ & $\mathbf{8 . 1 6}$ & $\mathbf{- 0 . 5 3}$ &
\end{tabular}

Source: Authors' calculations on the basis of RGFI data (Annual Financial Statements Registry)

\section{CONCLUSION}

The paper aimed at assessing the financial condition of the select activities in the observed period on the basis of data obtained from the Financial Agency on a sample consisting of 50 small and medium-sized Croatian companies in the period 2008-2014. To that end, the following research question was posed: Does the entire Croatian economy depend on the financial performance of small and medium-sized companies in select activities? In order to find the answer to the said question, the analysis of the select activities was conducted by analysing liquidity, leverage, ROA and ROE ratios. The conducted research showed the dependence of an economy on the performance of specific activities. The service activities such as professional activities, administrative and support service activities, transport and storage as well as other service activities showed a high level of profitability unlike trade characterized by very low profit margins which might also be affected by competition. As small and medium-sized companies showed poor management of current assets, regular implementation of collection measures or shorter stock holding periods must be carried out in order to increase their profitability. High gearing leads to a conclusion that it is necessary to decrease the financial risk exposure of the observed companies ranging from $46 \%$ to $103 \%$. In any case, it has an effect on the Croatian economy as a whole.

The research should be expanded and the structure of the current assets, the liabilities and the capital of SMEs analysed. The possibility of eliminating deficiencies and achieving adequate financial results which will also have an impact on the national economy should also be assessed. 


\section{LITERATURE}

Belak V. (2014) Analiza poslovne uspješnosti: 130 ključnih pokazatelja performanse i mjerila za kontroling (The Analysis of Business Success: 130 key performance indicators and Controlling Measures), Zagreb : RRiF plus

Bistričić, Agatić, Trošić (2011). Značaj poslovanja malih i srednjih poduzeća u gospodarstvu Republike Hrvatske i gospodarstva zemalja Europske Unije (The Importance of Small and Medium- sized Enterprises in the Croatian Ekonomy and the European Union States Ekonomies). Rijeka: Časopis Pomorstvo, 25/1, 145 -158 (Scientific Journal of Maritime Research, 145-158)

Dudić, Z., Cvijić, M. (2017). Development of Small and Medium -sized Enterprises in the Republik of Serbia and the Republic of Croatia, Education for Entrepreneneurship, Vol.7 NR1,129 -140, available on: https://hrcak.srce.hr/183428

Džafic, Z. (2014 ). Pravci rasta i razvoja bosansko hercegovačke privrede - mala i srednja vs. velika poduzeća, (Patterns of Growth and Development of the BIH Economy - Small and Medium Versus Large Companies) available on: https://www.researchgate.net/profile/Zijad_Dzafic/

Gospodarska kretanja 3/4/2017 (2017) - (Economic Trends), Croatian Chamber of Economy, available on: https://www.hgk. hr/documents/gospodarskakretanja030459253b851794d. pdf

Juračak, J., Pranjić, D. (2014). Mala i srednja poduzeća u uvjetima gospodarske krize u Hrvatskoj (Small and Medium-Sized Companies in Times of Economic Crisis in Croatia), Faculty of Agriculture Osijek, 49th Croatian \& 9th International Symposium on Agriculture, Dubrovnik, 146-150.
Nanić, A. (2011). Mala i srednja poduzeća kao nosilac razvoja privrede europske unije (Small and Medium Enterprises as Head of Business of the European Union), available on: https://hrcak.srce.hr/file/159709

Vujčić, B. (2016). Gospodarski izgledi u 2016. godini - jačanje konkurentnosti i rast (Economic Forecast in 2016 - Strengthening of Competition and Growth). 19th Scientific Conference on the Croatian Financial Market (Hrvatsko novčano tržište), Opatija, available on https://www.hnb.hr/documents/20182/497904/hn05052016_Vujcic_govor_Opatija. pdf/10b34d0e-a4a1-4b66-aa2b-d4f69dee547f?version=1.4

Žager K., Mamić Sačer I., Sever Mališ S., Ježovita A. \& Žager L. (2017). Analiza financijskih izvještaja (The Financial Statements Analysis). Third amended and supplemented edition. Zagreb: Croatian Association of Accountants and Financial Experts

Zakon o računovodstvu (Accountancy Act), Narodne novine (Official Gazette) 78/2015, 34/2015, 120/2016.

Zakon o poticanju razvoja malog gospodarstva (Act on Stimulating Small Business Growth), Narodne novine (Official Gazette) 29/2002, 63/2007, 53/2012, 56/2013, 121/2016.

Nacionalna klasifikacija djelatnosti 2007 (National Classification of Activities 2007), Narodne novine (Official Gazette) $58 / 2007$

Registar godišnjih financijskih izvještaja http://rgfi.fina.hr (Annual Financial Statements Registry)

Hrvatski poslovni portal, http://www.poslovna.hr (Croatian Business Portal) 